\title{
切削屑添加による鋳造アルミニウムの結晶粒微細化*
}

\author{
田伏 賢一*.佐藤 尚**.渡辺 義見**
}

Journal of The Japan Institute of Light Metals, Vol. 63, No. 4 (2013), 147-153

(C) 2013 The Japan Institute of Light Metals

\section{Grain refinement performance of aluminum cast using machining chips}

\author{
Kenichi TABUSHI*, Hisashi SATO** and Yoshimi WATANABE**
}

\begin{abstract}
Grain refinement performance of as-cast aluminum using machining chip of aluminum was studied. For this purpose, aluminum machining chips with different shape were fabricated. Aluminum wire is also used for the aluminum cast as model material of grain refiner. It is found that the machining chips act as the grain-refiner, since the lattice disregistry towards aluminum is absolutely zero. Moreover, higher cooling rate for aluminum cast with chips also influences on the grain refining of the as-cast aluminum. Although some pore and gap were found for the ascast aluminum with the machining chips, these defects can be reduced when the mold is preheated.
\end{abstract}

(Received October 8, 2012 Accepted January 21, 2013)

Keywords: casting, machining chip, grain refinement, lattice disregistry re-use

\section{1. 緒言}

切削などの除去加工においては，加工時に切削屏の発生を 伴う。加工時に発生する切削屑の再利用法として, 溶解炉に てインゴットと共に切削屑を再溶解する方法が一般的であっ た ${ }^{1), 2)}$ 。これに対し，再溶解することなく，材料や製品の素 材とする研究も報告されている3 ${ }^{3)}$ 。例えば, 會田らはド ライ切削加工により得られたAZ31マグネシウム合金切削屑

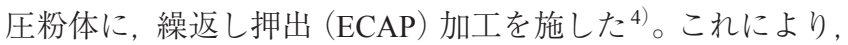
微細結晶粒組織を有する均質固化材の作製が可能であること を示している。また，高橋らは切削屑に強ひずみ加工である 圧縮ねじり加工を施し, 固化材の作製を行っている7)。我々 は金属間化合物の原料とする手法 ${ }^{8)}$, 複合材料の強化相とし て利用する手法9)などを提案してきた。最近では，切削屑 を利用した遠心鋳造の可能性に関して研究を進めている ${ }^{10)}$ 。 この手法は傾斜機能材料製造法である遠心力混合粉末法を鋳 造品製造法に転用したものであり，概要は以下である ${ }^{11), 12) 。 ~}$ まず，母材金属と同一組成の切削屑を金型内に配置し，金型 を回転させる。その後, 金型中へ母材金属の溶湯を注湯する。 その際，母材金属溶湯は，遠心力による加圧のため，切削屑 の隙間にくまなく行き渡る。同時に，注湯した母材金属溶湯 の熱により金型内に配置された切削屑の一部が融解する。こ の状態で冷却を行えば，健全な鋳造製品が得られ，切削屑を 溶解炉にて再溶解することなくリサイクルすることが可能と なる。これまで，我々は，本手法を検証するために，切削屑 と溶湯にアルミニウムを用いた遠心鋳造実験を行い, 溶解に 必要なエネルギーを減らすことが可能であることを示してい
る ${ }^{10)}$ 。さらに, 得られた遠心鋳造材の組織を詳細に調べ, 切削屑の添加により鋳造材の結晶粒微細化が認められること を報告している。結晶粒が微細化した要因としては，以下の 2つの要因を考えている。ひとつ目の要因は, 添加した切削 屑がアルミニウム溶湯の熱を奪い, 凝固を促進させたことで ある。もうひとつの要因は, アルミニウム溶湯が凝固する際 に, 残存した切削屑が核生成サイトとして作用することであ る。しかし，遠心鋳造を用いた実験に拈いては，高速回転す る金型内での凝固現象を調査する必要があり, 要因解明には 至っていない。

本研究では, 切削屑によるアルミニウム鋳造材組織微細化 の要因の究明を目的とした。切削屑による組織微細化の現象 を単純化するため, アルミニウム切削屑扔よび純アルミニウ ム線材を用いて重力鋳造によりアルミニウムの鋳造を行っ た。詳細は結果にて記述するが, 結晶粒微細化の現象は両要 因が重畳すると結論された。なお，本論文中のアルミニウム

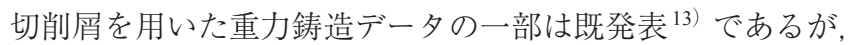
それにアルミニウム線材を用いて実験デー夕を加え，それら を元に組織形成機構に関して詳細に検討した。

\section{2. 実験方法}

\section{1 切削屑を利用した鋳造実験}

本実験では，純度 $99.7 \%$ のアルミニウムを供試材とした。

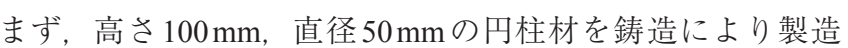
し，このアルミニウム鋳造材に対して旋盤加工を施した。切 削速度および送りは，それぞれ $72 \mathrm{~m} / \mathrm{min}$ および $16 \mathrm{~mm}$ の条件 とし，切込厚さを $0.2 \mathrm{~mm}, 0.4 \mathrm{~mm}$ および $0.6 \mathrm{~mm}$ に変化させて

\footnotetext{
*名古屋工業大学大学院院生（广466-8555 愛知県名古屋市昭和区御器所町）〔現在：株式会社マキ夕〕 Graduate Student, Department of Engineering Physics, Electronics and Mechanics, Graduate School of Engineering, Nagoya Institute of Technology (Gokiso-cho, Showa-ku, Nagoyashi, Aichi 466-8555) 〔Present: Makita Corporation].

**名古屋工業大学 (名古屋市)。Department of Engineering Physics, Electronics and Mechanics, Graduate School of Engineering, Nagoya Institute of Technology (Nagoya-shi, Aichi).E-mail: yoshimi@nitech.ac.jp
} 

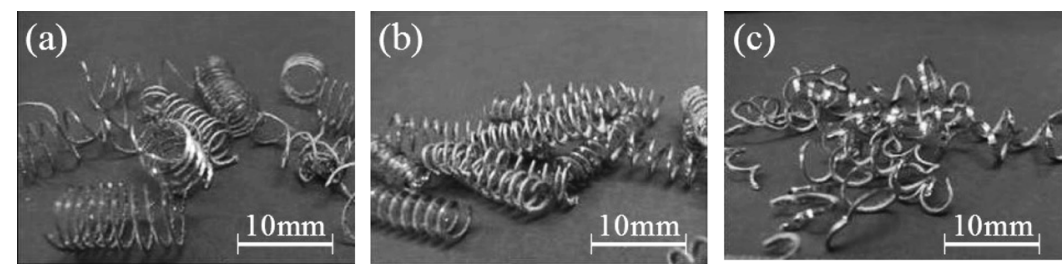

Fig. 1 Photographs of aluminum machining chips. Depth of cut was (a) $0.2 \mathrm{~mm}$, (b) $0.4 \mathrm{~mm}$ and (c) $0.6 \mathrm{~mm}$.

Table 1 Dimensions of obtained machining chips.

\begin{tabular}{c|c|c}
\hline \hline $\begin{array}{c}\text { Depth of cut, } \\
z / \mathrm{mm}\end{array}$ & Width, $w / \mathrm{mm}$ & Thickness, $t / \mathrm{mm}$ \\
\hline 0.2 & 0.66 & 0.47 \\
0.4 & 0.89 & 0.63 \\
0.6 & 1.26 & 0.66 \\
\hline
\end{tabular}

Table 2 Experimental conditions for Samples 1 to 8.

\begin{tabular}{|c|c|c|c|}
\hline \multirow{2}{*}{$\begin{array}{l}\text { Sample } \\
\text { No. }\end{array}$} & \multicolumn{2}{|c|}{ Used machining chips } & \multirow{2}{*}{$\begin{array}{c}\text { Mold } \\
\text { temperature, } \\
T /{ }^{\circ} \mathrm{C}\end{array}$} \\
\hline & $\begin{array}{l}\text { Depth of cut, } \\
z / \mathrm{mm}\end{array}$ & $\begin{array}{c}\text { Amount, } \\
M / \mathrm{g}\end{array}$ & \\
\hline 1 & \multicolumn{2}{|c|}{ Non } & \multirow{4}{*}{23} \\
\hline $\begin{array}{l}2 \\
3\end{array}$ & 0.2 & $\begin{array}{l}10 \\
16\end{array}$ & \\
\hline $\begin{array}{l}4 \\
5\end{array}$ & 0.4 & $\begin{array}{l}10 \\
16\end{array}$ & \\
\hline $\begin{array}{l}6 \\
7\end{array}$ & 0.6 & $\begin{array}{l}10 \\
16\end{array}$ & \\
\hline 8 & 0.2 & 16 & 300 \\
\hline
\end{tabular}

3種類の切削屑を作製した。その後，作製した切削屑を，ア セトンによって脱脂し，切削屑の長さが $20 \mathrm{~mm}$ 以内になるよ うに切断した。Fig. 1 は作製した切削屑である。いずれの条 件に扔いても螺旋形状をしているが，切込厚さによって螺旋 の形状は異なっていた。作製した切削屑の幅と厚さを測定し た結果を Table 1 に示す。切込厚さが増加すると幅と厚みが 大きくなっていることがわかる。

作製した切削屑を利用して重力鋳造を行った。鋳造条件を Table 2 に示す。本実験では，切込厚さが異なる切削屑を用 い，かつ切削首の添加量を変化させて鋳造を行った。鋳造試 験で用いた金型の形状掞よび寸法を Fig. 2 に示す。まず，金 型内部に切削屑を添加した。このとき, 中央部の $\phi 10 \mathrm{~mm}$ の 領域には湯道確保のため, 切削屑を添加しない領域を設け た。添加量の多い条件に打いては，上部より力を加えて切削 屑を圧縮し，装填した。切削屑を添加後，金型上部の蓋をね じにより固定した。そして, 純度 $99.7 \%$ のアルミニウムイン

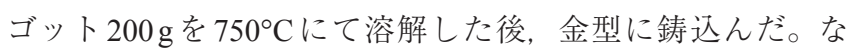
お，鋳放したままにて放置し，冷却を行った。その後，試料 底面から $10 \mathrm{~mm}$ の位置にて切断し, この面を組織観察面とし て固定した。

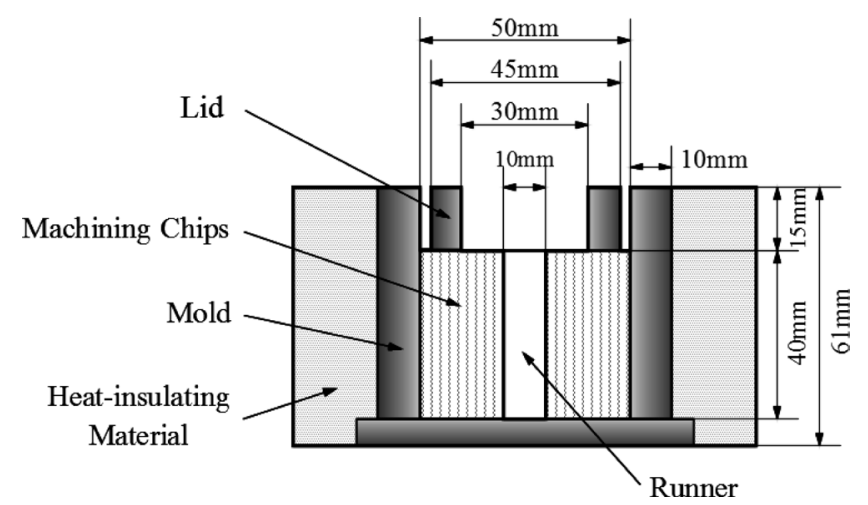

Fig. 2 Schematic illustration of casting mold.

Table 3 Casting conditions of Specimens A to E.

\begin{tabular}{c|c|c|c|c}
\hline \hline $\begin{array}{c}\text { Sample } \\
\text { No. }\end{array}$ & $\begin{array}{c}\text { Wire } \\
\text { material }\end{array}$ & $\begin{array}{c}\text { Wire } \\
\text { diameter, } \\
D / \mathrm{mm}\end{array}$ & $\begin{array}{c}\text { Amount, } \\
M / \mathrm{g}\end{array}$ & $\begin{array}{c}\text { Surface } \\
\text { area, } \\
A / \mathrm{mm}^{2}\end{array}$ \\
\hline \multirow{2}{*}{$\mathrm{A}$} & \multicolumn{4}{|c}{ Non } \\
\hline B & & 1.0 & 5 & 6.0 \\
$\mathrm{C}$ & \multirow{3}{*}{$\mathrm{Al}$} & 10 & 12 \\
\cline { 3 - 5 } $\mathrm{D}$ & & 2.0 & 5 & 3.0 \\
$\mathrm{E}$ & & 10 & 6.0 \\
\hline
\end{tabular}

\section{2 モデル切削屑による鋳造実験}

切削屑による結晶粒微細化メカニズム解明のため, 形状の 複雑な切削屑の代わりに形状が単純な線材を使用した鋳造実 験も行った。使用した線材は, 直径 $\phi 1.0$ あるいは $\phi 2.0 \mathrm{~mm} の$ 純アルミニウム（純度 $99.99 \%$ ）である。これらを用いて， Table 3 に示すように線材の直径扮よび添加量を変化させて 鋳造を行った。 $36 \mathrm{~mm}$ に切断した線材を穿孔した $80 \mathrm{~mm} \times$ $90 \mathrm{~mm} \times 6 \mathrm{~mm}$ の $\mathrm{S} 45 \mathrm{C}$ 鋼板に挿入した。ただし, 湯道となる 部分には，線材を設置しないことで湯流れを確保した。この 鋼板を金型の底部に配し, $750^{\circ} \mathrm{C}$ に加熱溶解した純アルミニ ウム $(99.7 \%) 200 \mathrm{~g}$ を注湯した。冷却速度の変化を調べるた めに, 試料底面から $10 \mathrm{~mm}$ の位置に抢いて金型に細穴を設 け，その細穴より熱電対を挿入して温度測定を行い，かつこ の位置を含む円断面を組織観察面とした。なお，複数回鋳造 実験を行い再現性について確認している。

\section{3 材料評価}

作製した鋳造材の組織観察を光学顕微鏡㧍よび走査型電子 顕微鏡により調査した。観察用試料の作製方法は前報告 ${ }^{10)}$ と同一である。

強度評価のため, 圧縮試験をインストロン型引張圧縮試験 
機により行った。詳細は結果で述べるが，作製した試料に おいては，位置によって粒径が異なっていた。そこで，外周 領域と内部領域と分けて, 各々の鋳造条件に対し 2 種類の $6 \mathrm{~mm} \times 6 \mathrm{~mm} \times 6 \mathrm{~mm}$ の立方体形状試験片を作製した。エメリー 紙を用いた研磨後，圧縮試験に供した。圧縮方向は鋳造水平 面に対して鉛直方向とし, 圧縮速度が $0.005 \mathrm{~mm} / \mathrm{s}$ の条件にて 行った。

\section{3. 実験結果と検討}

\section{1 切削屑を利用した鋳造材の組織}

Fig. 3(1) から（7）は，それぞれ試料 1 から 7の組織写真 である ${ }^{13)}$ 。Fig. 3(1）の組織写真より，切削屑を利用してい ない鋳造材は，粗大な組織を有していた。これに対して，切 削屑の添加を行って作製したすべての試料においては，Fig．
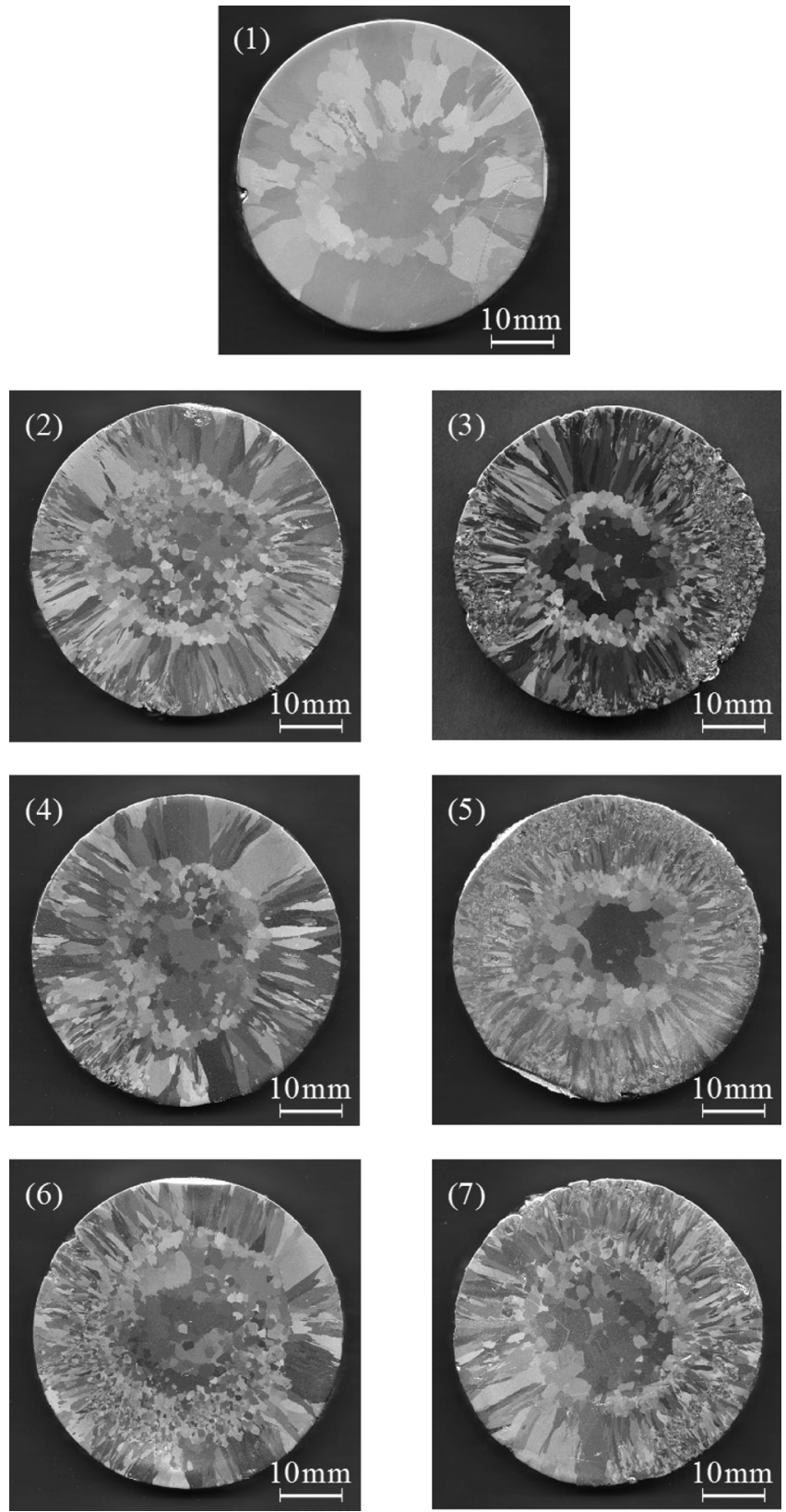

Fig. 3 Macrostructures of the as-cast aluminum samples with and without the machining chips ${ }^{13)}$. (1) to (7) correspond to samples No. 1 to No. 7, respectively.
3（2）から（7）に示すように微細な結晶粒が観察された。一 般的に, 結晶粒微細化剂を利用した場合, 鋳造組織全体が微 細化される ${ }^{14)}$ 。一方で, Fig. 3(2) から（7）より，切削首を 添加した場合は，位置により結晶粒径が大きく変化してい た。この不均一性を調査する目的で垂直断面組織を観察した ところ, 中央付近の結晶粒は熱流に沿った柱状晶の一部であ ることがわかった。すなわち，鋳型側面は断熱材で覆われて いるため，熱は側面のみならず底面からも同時に抜熱され る。このような熱的状態により, 側面および底面から柱状晶 が伸びた。本実験では，底面から近い場所を切断して観察し たため，結果として不均一な組織として観察された。

この切削屑添加による結晶粒微細化能を議論するには, 本 来ならば柱状晶の切断面を除外して考察すべきであるが, そ のためには各々の結晶粒の 3 次元的な形状評価が必要とな る。本研究では, 簡便のため微細化観察面における結晶粒の 数を計測し，それを観察面の面積で除した值を評価基準とし た。結果をFig. 4 に示す。図のように, いずれの試料も切削 屑を利用することで結晶粒は約 $50 \%$ までに微細化していた。 試料 2 と 3 , 試料 4 と 5 および試料 6 と 7 の比較により, 微細 化能は添加した切削屑の増加に伴い強まることがわかる。試 料 2 と 4 と 6 および試料 3 と 5 と 7 の比較により，切削屑作製 時の切込厚さ, すなわち切削屑の寸法の変化によっても微細 化能が異なることも見出された。しかし, 切削居の寸法の影 響に関しては系統だった影響は見出されていない。結晶粒微 細化の要因としては, 残存切削屑による核生成効果と切削屑 添加による抜熱効果が考えられる。この要因に関して議論す るため, 切削屑を線材に変えてモデル実験を行った。その結 果を次節で説明する。

\section{2 線材を利用した鋳造材の組織}

前節から切削屑の添加は, 鋳造材の結晶粒微細化を促進す ることが認められた。この結晶粒微細化の要因の一つは, 結 晶粒微細化剂を利用した鋳造組織微細化と同じメカニズムで ある。これは，異質核物質を溶湯中に分散させて核生成サイ 卜数を増加させることで，鋳造材の結晶粒微細化を促進する ものである。有効な異質核となるためには, 異質核物質と母 相結晶の界面エネルギーが小さい方がよいとされており, 界 面エネルギーを小さくするためには, 異質核とその表面から 形成する母材結晶との格子の整合性がよいことが必要であ る ${ }^{15)}$ 。Turnbull と Vonnegutは，異質核物質と母相との結晶格 子の低指数面における 1 方向の原子配列の不整合度 $\delta$ を次の

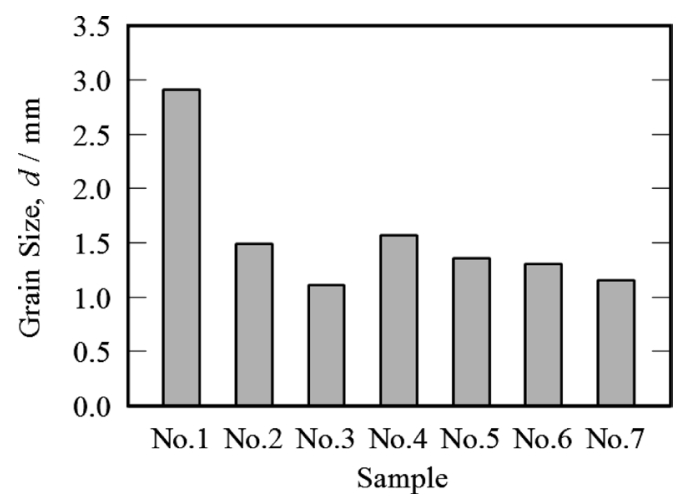

Fig. 4 Mean size of $\alpha$-Al grain for as-cast aluminum samples with and without the machining chips. 
ように定義し，異質核生成の有効性について議論した ${ }^{16) 。 ~}$

$$
\delta=\frac{\left|a-a_{0}\right|}{a_{0}} \times 100 \quad[\%]
$$

ここで， $a_{0}$ および $a$ は，それぞれ母材結晶および異物質の低

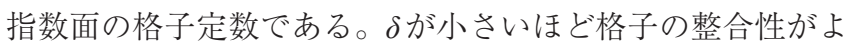

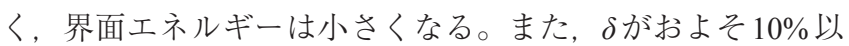
下であれば整合性はよいと言われており，その異質物は有効 な異質核とみなせる。純アルミニウムの異質核としてはよく 知られた $\mathrm{Al}_{3} \mathrm{Ti}$ 粒子 ${ }^{15)}$ は $\mathrm{D}_{22}$ 構造を有し, $a$ 軸方向と $c$ 軸方 向とでは格子定数が異なる $(a=0.3851 \mathrm{~nm}, c=0.8608 \mathrm{~nm}) 。 \mathrm{fcc}$ 構造の純アルミニウムの格子定数は $a_{0}=0.4049 \mathrm{~nm}$ であり，

$$
(001)_{\mathrm{Al}} / /(001)_{\mathrm{Al}, \mathrm{Ti}}, \quad[100]_{\mathrm{Al}} / /[100]_{\mathrm{Al}, \mathrm{Ti}}
$$

の結晶方位関倸 ${ }^{17)}$, 18) の場合, 不整合度 $\delta$ は $4.9 \%$ となる。この 值は $10 \%$ より充分に小さく, $\mathrm{Al}_{3} \mathrm{Ti}$ は有効な異質核物質とし て働く。本研究で使用した純アルミニウム切削屑が溶湯に残 存した場合，新たに核形成する必要がなく，その既存固相の 成長により凝固が進行する。この既存固相の成長は，不整合 度の面から考えた場合， $\delta=0 \%$ という特殊な場合に相当する であろう。

一方, 添加した切削屑が溶融アルミニウムから熱を奪う抜 熱現象も結晶粒微細化の要因の一つであろう。これは，3種 類に分類することができる。まず，1番目として固相状態に 扔ける切削屑が，室温から溶湯温度までに加熱するときに必 要な熱量である。質量 $m$ の物質を $T_{1}$ から $T_{2}$ に温度を上げる のに必要な熱量 $Q$ は

$$
Q=\int_{T_{1}}^{T_{2}} m C_{\mathrm{p}} \mathrm{d} T
$$

で与えられる。ただし， $C_{\mathrm{p}}$ は定圧比熱であり，その温度 $T$ 依 存性は

$$
C_{\mathrm{p}}=\mathrm{a} T^{\mathrm{b}} \mathrm{e}^{\left(\mathrm{c} T+\frac{\mathrm{d}}{T}\right)}
$$

で表記できる ${ }^{19)}$ 。ここで, a, b, c およびdは定数であり，ア ルミニウムの場合, $\mathrm{a}=26.219, \mathrm{~b}=-0.5469, \mathrm{c}=0.000925$ お よ び $\mathrm{d}=-156.932$ が $-231^{\circ} \mathrm{C}$ から $650^{\circ} \mathrm{C}$ の間で成立つ ${ }^{19)}$ 。以上に より， $303 \mathrm{~K}$ (室温, $\left.30^{\circ} \mathrm{C}\right)$ から $933 \mathrm{~K}\left(660^{\circ} \mathrm{C}\right)$ まで加熱す るときに必要な単位質量あたりの熱量を計算すると,

$$
\int_{303}^{933} 26.219 \times T^{-0.5469} \times e^{\left(0.000925 T+\frac{-156.925}{T}\right)} \mathrm{d} T=678 \mathrm{~kJ} / \mathrm{kg}
$$

となる。2番目として, 切削屑が融解するときに奪う融解熱 も考慮する必要がある。固相アルミニウムが融解するときの 単位質量あたりの融解熱は $397 \mathrm{~kJ} / \mathrm{kg}$ である。これらは, 切削 屑の質量に比例する量であるが，切削屑が部分的に融解する 場合は，融解は表面から生じるためその融解量は切削屑の表 面積に比例するであろう。さらに，3番目として，伝熱効果 である。溶融アルミニウムに比べて，固相アルミニウムの熱 伝導率が高いため, 固相アルミニウムを伝わり金型に熱が放 出されやすい。この場合, 溶融アルミニウムと固相アルミニ ウムとの接触面積に依存するため, 切削屑の表面積に関係す る値となるであろう。これらの抜熱により周囲の溶融アルミ ニウムの熱を奪い，局所的に温度が下がる。結果として，そ
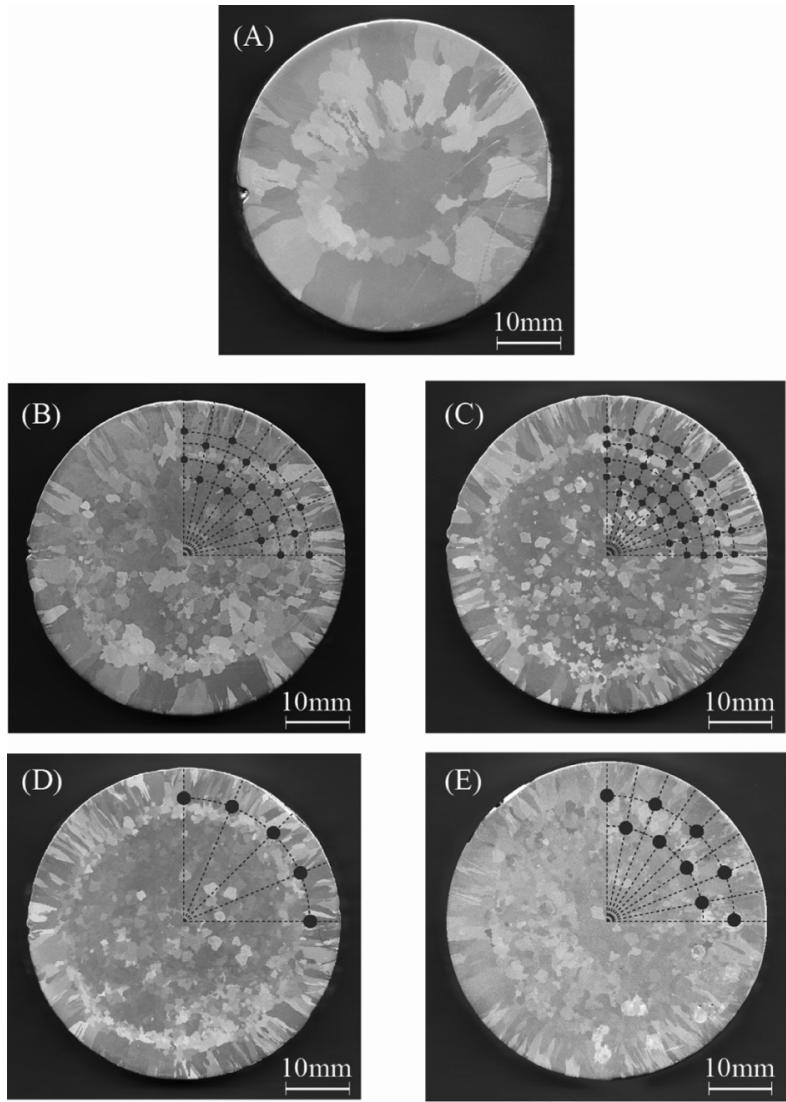

Fig. 5 Macrostructures of the as-cast aluminum samples with and without the aluminum wire. (A) to (E) correspond to samples No. A to No. E, respectively.

の部位での局所的冷却速度の増加が見込まれ, 結晶粒微細化 が生じるものと考えられる。

結晶粒微細化の要因を議論するため, 不整合度 $\delta=0 \%$ の純 アルミニウム線材を用い, その表面積掞よび質量を変化させ たモデル実験を行った。このモデル実験では, 任意の位置に 線材が配置できるので, 溶湯注入による線材の融解に関して も議論できるメリットを有する。得られた鋳造材試料の組織 観察写真を Fig. 5 に示す。Fig. 5(A) は純アルミニウム線材 を用いていない試料 Aの結果であり, Fig. 5(B) から (E) は純アルミニウム線材を用いた試料 $\mathrm{B}$ から試料 $\mathrm{E}$ の結果であ り,これら各組織写真の右上半分に線材を配した位置を示 す。アルミニウム線材を用いたことで, 結晶粒が微細化した ことがわかる。

これら鋳造材の結晶粒径を Fig. 6 に示す。試料 B と試料 C との比較, 抒よび試料 $\mathrm{D}$ と試料 $\mathrm{E}$ との比較により, 切削屑の 実験同様, 添加量の増加に伴い微細化能が向上することがわ かる。この結晶粒径を, 添加したアルミニウム線材の表面積 によって整理した図がFig.7である。添加したアルミニウム 線材の表面積が増加するにつれて, 鋳造材の結晶粒径は小さ くなっている。この結果は切削屑を利用した鋳造材に扔いて も同様の現象が生じると考えられる。そのため, 添加量に対 して表面積の大きな切削屑を用いることで, 結晶粒微細化効 果を向上させることが可能である。しかしながら, 線材表面 積が同一であるにもかかわらず，添加量が異なる試料 $\mathrm{B}$ と試 料 $\mathrm{E} と に$ 打いても, 若干の微細化能の差異がある。アルミニ ウム線材の核生成サイト効果, アルミニウム線材の部分的融 


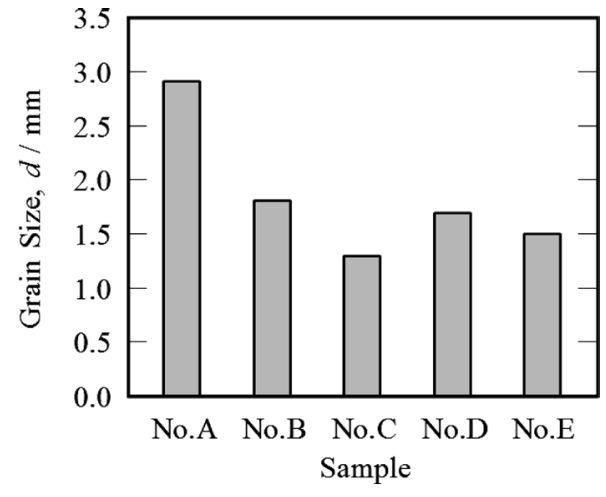

Fig. 6 Mean size of $\alpha-\mathrm{Al}$ grain for as-cast aluminum samples cast with and without the aluminum wire.

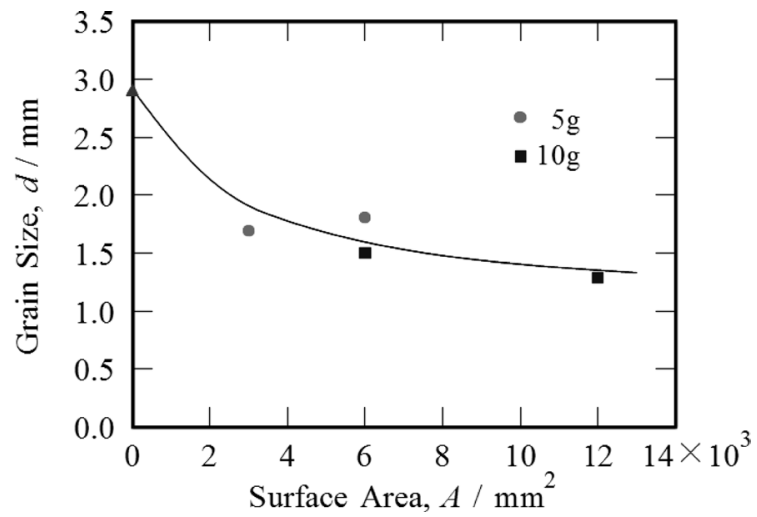

Fig. 7 Grain size of Samples A to E as a function of surface area of added aluminum wire.

解に伴う抜熱効果およびアルミニウム線材の伝熱効果による 微細化能は, 添加量より線材表面積に強く依存するであろ う。したがって，この差異はアルミニウム線材が室温から溶 湯温度までに温度上昇に使われた抜熱効果によるものと考え られる。

この抜熱効果は鋳物全体の冷却速度へも影響するであろ う。そこで，アルミニウム線材の表面積が鋳造材の冷却速度 に与える影響について調べた。Fig. 8 は添加したアルミニウ ム線材の表面積と冷却速度の関係を示している。図より，ア ルミニウム線材添加により凝固速度が増加することがわか る。これは，添加したアルミニウム線材の温度上昇に費やさ れた熱量, 融解に必要な融解熱およびアルミニウム線材の伝 熱により外部に放出された熱により，溶融アルミニウムの温 度が低下したためである。同一の添加量でもアルミニウム線 材の表面積が増加するにつれて冷却速度が速くなる。同一の 表面積を有する場合, 線材の添加量を増加させると, 冷却速 度も増加するが，その変化は大きくはない。アルミニウム線 材の融解に伴うエネルギー消費は，アルミニウム線材の加熱 に必要な熱エネルギーに比較して小さいため,アルミニウム 線材の抜熱効果としては，伝熱による金型への熱放出の影響 が大きいことがわかる。

逆に，このことは，アルミニウム線材が完全溶融した後に は，その局所的部位での冷却速度の促進が認められないた め, 微細化効果が生じないことを意味する。アルミニウム線

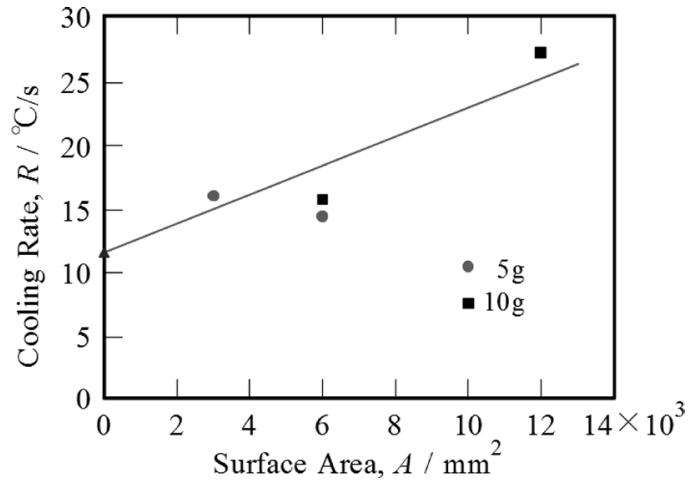

Fig. 8 Cooling rate of as-cast aluminum as a function of surface area of added aluminum wire.
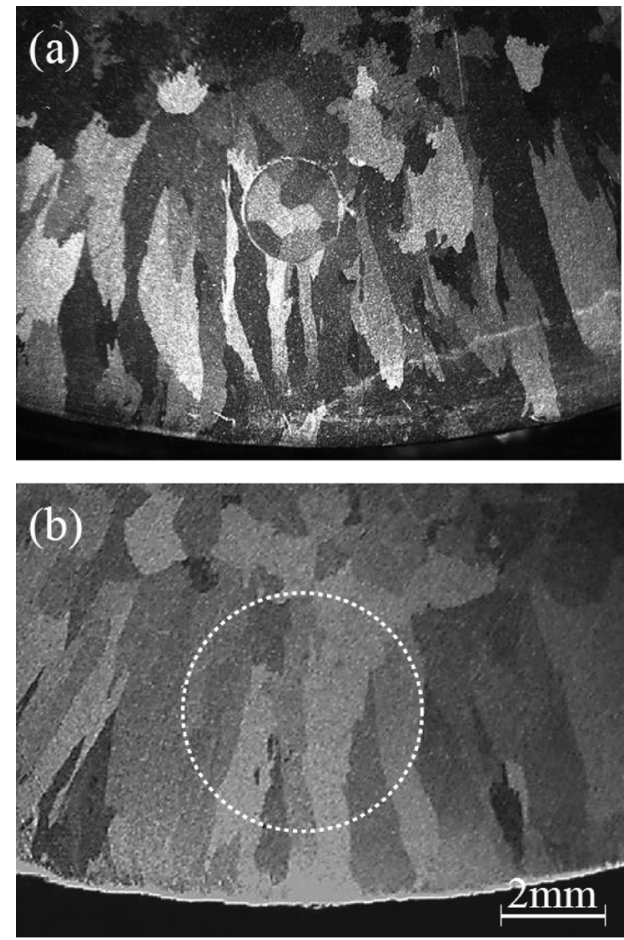

Fig. 9 Microstructures of Sample D at different position.

材を用いた鋳造材（試料D）の微細組織写真を Fig. 9に示す。 Fig. 9(a) において, 中央付近の丸い部分が線材である。ア ルミニウム線材の周囲には, 大きさは異なるが柱状晶が成長 していた。これらの結晶粒は線材を利用していない場合の結 晶粒よりも微細化していた。このように，融解が完了するま での線材は微細化能を有する。線材を用いたモデル材料で は，線材を配置した位置が特定できるので，前述のように線 材の融解に関しても議論が可能である。同一鋳造材において は, Fig. 9(b) の点線内に示すように, 線材が完全に融解し た部位も観察された。線材が完全に融解した場合, 線材が存 在した部分とその周辺の結晶粒の成長には大きな差異は観察 されなかった。したがって，線材が完全に融解した場合は， その位置における局所的な融解熱の影響は小さいと考えられ る。

\section{3 切削首を利用した鋳造の実用化}

本技術の実用化に当たっては, 鋳造材の強度の確保が不可 欠である。そこで，得られた鋳造材の圧縮試験を行い， $0.2 \%$ 


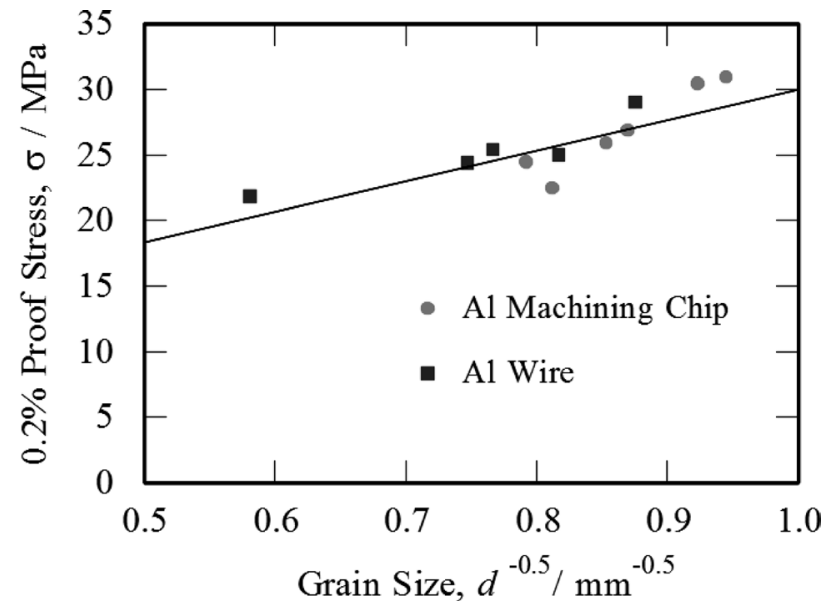

Fig. $10 \quad 0.2 \%$ proof stress of as-cast aluminum samples.

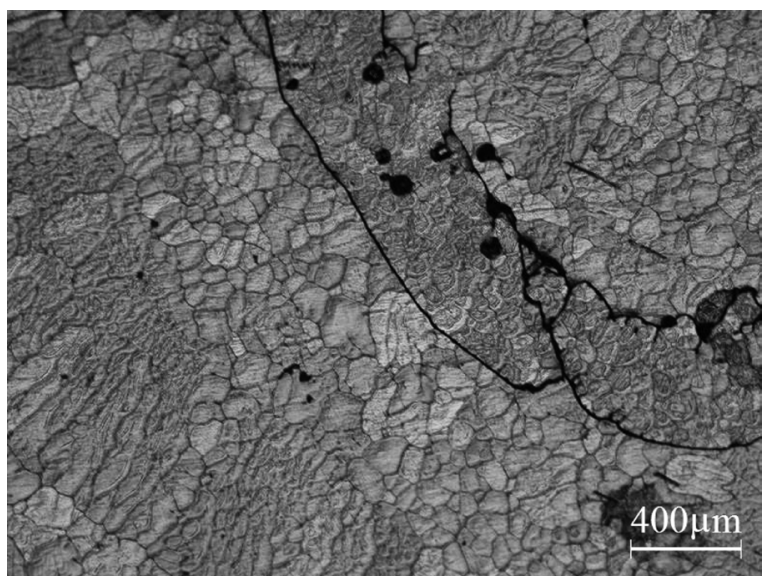

Fig. 11 Microstructure around a retained machining chip in Sample 3.

耐力を調査した。Fig. 10はアルミニウム切削屑およびアルミ ニウム線材を用いた鋳造材の $0.2 \%$ 耐力を結晶粒径の- 0.5 乗 で整理したグラフである。各試料の位置による差異はわずか であったため, 平均值をプロットしている。結晶粒が微細な ほど $0.2 \%$ 耐力は向上しており，切削屑を用いた鋳造材の $0.2 \%$ 耐力も線材を用いた鋳造材の $0.2 \%$ 耐力もホールペッチ の法則に従うことがわかった。このように，切削屑あるいは 線材を添加することにより，強度の高い鋳造材を提供するこ とが可能となった。ここで注目すべき点は, 添加している物 質が鋳造材と同じ組成であることである。したがって，不純 物を増加させることなく微細化が達成できる。

鋳造欠陥を含まない健全な鋳物を提供することも，本技術 の実用化には必要条件である。微視的鋳造欠陥の有無を調査 する目的で，切削屑を利用して製造した鋳造材における未融 解の切削屑付近の組織を Fig. 11 に示す。切削屑と母相との 間に非常に薄い隙間が確認できる。その間隔は $10 \mu \mathrm{m}$ 程度で あった。このような鋳造欠陥は, 試料外周部に多く観察され た。さらに未融解の切削屑の周囲にはマク口観察によると大 きな凹部が見出された。これは, 切削屑を利用したことで鋳 込み時の湯流れが複雑になり, 溶湯が空気を巻込むことに起 因する。

切削屑を用いた遠心鋳造において，鋳造欠陷発生抑制には 金型の予備加熱が有効であることが見出されている。本研究

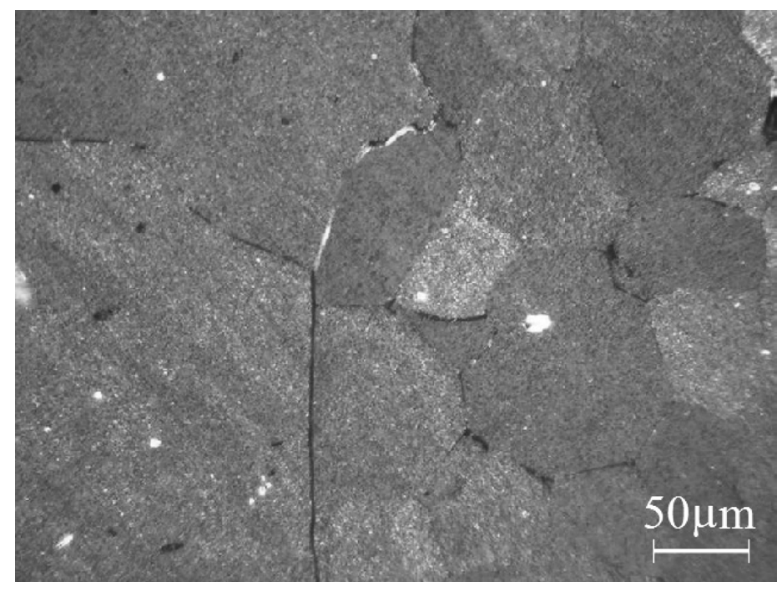

Fig. 12 Microstructure around a retained machining chip in Sample 8.

においても, 湯流れを改善するために, 金型をあらかじめ $300^{\circ} \mathrm{C}$ まで予備加熱して鋳造を行い試料 8 の作製を行った。 試料 8 における結晶粒径は $1.31 \mathrm{~mm}$ であった。金型を予備加 熱していない試料 3 と比較すると，10\%程度結晶粒径が大き くなった。しかしながら，結晶粒が粗大化したにもかかわら ず, $0.2 \%$ 耐力は変化しなかった。これは, 結晶粒微細化効 果が薄れたにもかかわらず, 鋳造欠陥の発生が抑制され，相 殺されたためと考えられる。Fig. 12 に試料 8 の微細組織を示 す。図より, 切削屑と母相との界面の隙間が大幅に軽減され ていることがわかる。このように, 鋳造欠陥抑制のためには 金型の予備加熱が有効であることが確認された。

切削屑による結晶粒微細化は結晶粒微細化剂の利用と比べ て, 材料内部の不純物の量を低減できるという利点がある。 加えて, 切削屑を直接溶解することなく再利用するので, 環 境に配慮した技術と言える。ただし, 一般的に結晶粒微細化 剂を利用して結晶粒微細化を行った場合, 組織全体が均一な 微細組織を有することが理想とされているが, 切削屑を結晶 粒微細化材とした場合は, 微細化される領域が限定されてお り, 従来結晶粒微細化剂を使用した場合よりも微細化効果が 低い。そのため, 今後, 鋳造材組織の更なる均質化に関する 技術開発が必要であろう。

\section{4. 結言}

本研究では, 切削屑を添加した鋳造材における結晶粒微細 化の要因に関する調査を行った。この目的のため, アルミニ ウム切削屑もしくはアルミニウム線材を金型内に配置し，そ れにアルミニウム溶湯を注入するという鋳造実験を行った。 得られた結果を以下にまとめる。

（1）アルミニウム切削屑を鋳造時に添加することにより純 アルミニウム鋳造材の結晶粒は微細化した。この現象は切削 屑の増加に伴い顕著に生じた。

（2）アルミニウム線材を用いたモデル実験においても，線 材添加量の増加に伴い微細化能が向上した。添加したアルミ ニウム線材の表面積が増加するにつれて, 鋳造材の結晶粒径 は小さくなるが, 線材表面積が同一であるにもかかわらず, 添加量が異なる試料においても微細化能の差異がある。

（3）切削屑添加による鋳造材の結晶粒微細化は, 添加した 切削屑による抜熱効果と, 残存切削屑の核生成サイト効果の 
重畳によるものと結論した。

（4）切削首添加により，鋳造欠陥が発生するが，金型の予 備加熱によりこの発生は抑制できる。金型の予備加熱により 微細化能は若干弱まるものの, 鋳造欠陥抑制により, 強度の 高い鋳造材の提供が可能となった。

謝 辞

本研究は, 軽金属奨学会, 文部科学省 地域イノベーショ ン戦略支援プログラム (グローバル型 $)$ 東海広域ナノテク ものづくりクラスター〜，挍よび科学研究費補助金基盤研 究（C）の支援を受けた。ここに謝意を表する。

\section{参 考 文 献}

1）大西忠一：軽金属，46 (1996)，525-532.

2）川尻秀和，鵜島祐介，日比野敦：粉体㧍よび粉末治金，54 (2007), 722-729.

3）戸田裕之，澤村純平，小林俊郎：軽金属，54 (2004)，418-424.

4）會田哲夫，高过則夫，松木賢司，鎌土重晴，小島 陽：軽金属, 54 (2004), 532-537.

5）加藤寛敬，加戸真樹，田口祐介，鷲田一夫：粉体㧍よび粉末治 金, 52(2005), 84-88.

6）千野靖正，馬㴊 守：軽金属，57(2007)，250-255.
7）高橋 崇, 久米裕二, 小橋 眞, 金武直幸：軽金属, 59 (2009), 354-358.

8) K. Matsuura, Y. Watanabe and Y. Hirashima: ISIJ Int., 44 (2004), 1258-1262.

9）若槻哲平，佐藤尚，渡辺義見，丸山忠克：鉄と鋼，92 (2006)， 562-566.

10）渡辺義見, 田伏賢一, 佐藤 尚, 伊藤智啓, 大矢泰正：日本金 属学会誌, 75 (2011), 320-326.

11）渡辺義見, 佐藤 尚：ケミカルエンジニヤリング, $\mathbf{5 4}$ (2009), 249-254.

12) Y. Watanabe, Y. Inaguma, H. Sato and E. Miura-Fujiwara: Materials, 2 (2009), 2510-2525.

13) Y. Watanabe, K. Tabushi, H. Sato and E. Miura-Fujiwara: Mater. Sci. Forum, 654-656 (2010), 1444-1447.

14) Z. Zhang, Y. Watanabe, I.-S. Kim, X. Liu and X. Bian: Metall. Mater. Trans., A, 36A (2005), 837-844.

15）神尾彰彦：軽金属, 56 (2006)，496-501.

16) D. Turnbull and B. Vonnegut: Ind. Eng. Chem., 44 (1952), 1292-1298.

17) K. F. Kobayashi, S. Hashimoto and P. H. Shingu: Z. Metalkd. 74 (1983), 751-754.

18) K. Yamashita, I. Fujimoto, S. Kumai and A. Sato: Mater. Trans. JIM, 39 (1998), 824-833.

19) S. I. Abu-Eishah, Y. Haddad, A. Solieman and A. Bajbouj: Latin Am. Appl. Res., 34 (2004), 257-265. 